\title{
CHARACTER BASED INTERACTIVE MULTIMEDIA IN WRITING SHORTSTORY CLASS FOR PRIMARY SCHOOL GRADE 6
}

\author{
Cerianing Putri Pratiwi, Fauzatul Ma'rufah Rohmanurmeta \\ Universitas PGRI Madiun \\ cerianing@unipma.ac.id
}

Article History

accepted 09/07/2018

approved 01/08/2018

published 17/09/2018

\section{Keywords}

interactive multimedia, characters, writing short stories

\begin{abstract}
The purpose of this study is to find out the application of character-based interactive multimedia in learning to write short stories for primary school grade 6. The type of this research is qualitative descriptive. This study has verbal data, namely the results of recording character-based interactive multimedia implementation activities on learning to write short stories for primary school grade 6 . Nonverbal data in this study is the value of the evaluation of students' short story writing skills. Subjects in this study were teachers and students of grade 6 primary school. This study uses data collection techniques, namely (a) observation, (b) interviews, and (c) tests, (d) documentation. The technique used to analyze data analysis data is interactive data analysis techniques. There are three stages (a) data reduction, (b) data presentation, and (c) conclusion. The application of character-based interactive multimedia has been implemented in accordance with the plans that have been made by the teacher as outlined in the Learning Implementation Plan. Based on the results of the evaluations that have been given, the short story writing skills of primary school grade 6 are good enough. This was seen in the average writing value of $78.3 \%$ of 15 students. There were 5 students who received a score of 70 . There were 5 students who scored 80, while the other 5 students got a score of 85 . Minimum completeness criteria for Indonesian language study were 75 . It showed that there were 5 students who had not yet completed or $33.3 \%$, while students who have completed there are 10 students or as much as $66.7 \%$
\end{abstract}

Social, Humanities, and Education Studies (SHEs): Conference Series https://jurnal.uns.ac.id/shes

p-ISSN 2620-9284 e-ISSN 2620-9292 


\section{PENDAHULUAN}

Pendidikan merupakan hal yang penting. Pendidikan akan dikatakan berhasil apabila peserta didik mengalami perubahan menjadi lebih baik, baik perubahan dalam pengetahuan yang menjadi bertambah, penguasaan keterampilan semakin meningkat, dan perubahan positif sikap perilaku yang menuju pendewasaaan. Hal tersebut juga berlaku dengan pembelajaran bahasa. Di mana, seseorang diharuskan untuk mampu meningkatkan kemampuan yang meliputi ketiga aspek utama ranah pendidikan yakni meningkatkan pengetahuan berbahasa, meningkatkan keterampilan berbahasa, dan membangun sikap positif serta santun berbahasa. Ketiga aspek utama tersebut tertuang dalam empat keterampilan berbahasa, yaitu menyimak, berbicara, membaca, dan menulis. Hal tersebut sejalan dengan pendapat Tarigan (2008:1), yang menyatakan bahwa keterampilan berbahasa dalam kurikulum di sekolah biasanya mencakup empat segi, yaitu keterampilan menyimak, keterampilan berbicara, keterampilan membaca, keterampilan menulis.

Keterampilan menulis merupakan salah satu keterampilan yang penting untuk siswa. Pada dasarnnya, orang menulis dikarenakan ingin menyampaikan pikiran, pendapat, dan perasaannya kepada orang lain melalui tulisan, agar orang lain mengetahui apa yang menjadi pikiran dan perasaanmya. Hal itu sejalan dengan pendapat Tarigan (2008:3) yang menyatakan bahwa menulis adalah salah satu keterampilan berbahasa yang dapat digunakan untuk berkomunikasi dengan cara tidak langsung, tidak dengan bertatap muka dengan orang lain.

Keterampilan menulis merupakan keterampialn berbahasa yang bersifat aktif dan produktif. Keterampilan ini dikatakan aktif dan produktif karena keterampilan menulis menghasilkan suatu produk tulisan yang dapat dibaca oleh orang lain, dimana isi dalam tulisan mengandung ide, pikiran, gagasan penulis. Keterampilan menulis memiliki peran yang penting dalam pembelajaran bahasa. Salah satu peran yang sangat pentin yaitu keberhasilan siswa dalam mengikuti pembelajaran di sekolah banyak dipengaruhi oleh keterampilan menulis siswa. Selain itu, dengan dimilikinya keterampilan menulis, siswa bisa lebih kreatif dengan mampu menuangkan ide, pikiran, dan perasaan dalam bentuk tulisan. Oleh karena itu, pembelajaran menulis harus dilatihkan pada siswa sejak dini. Hal itu sejalan dengan pendapat Syafi'e (dalam Saddhono dan Slamet, 2012: 95) bahwa anak usia sekolah harus sedini mungkin menguasai keterampilan menulis.

Menulis sebagai keterampilan produktif membutuhkan ketepatan dalam penggunaan bahasa. Darmadi (1996: 1) berpendapat bahwa keterampilan menulis tidak diperoleh secara langsung, tetapi diperoleh melalui proses belajar. Proses belajar untuk melatih keterampilan menulis ini, dengan cara melalui latihan dan praktik yang banyak dan teratur. Hal itu dikarenakan keterampilan menulis tidak dimiliki oleh seseorang secara alamiah, akan tetapi diperoleh melaui kegiatan proses belajar dengan cara selalu berlatih.

Menulis merupakan suatu kegiatan yang produktif dan ekspresif. Pada saat menulis, seorang penulis harus mampu terampil dalam memanfaatkan kosa kata dan struktur bahasa. Agar dapat menulis dengan baik siswa harus dibekali pengetahuan yang cukup, selain itu juga, dapat diperoleh melalui kemauan untuk belajar dan berlatih dengan sungguh-sungguh.

Pada observasi yang dilakukan observasi, diketahui bahwa banyak siswa kurang terampil dalam menulis terutama menulis cerita pendek. Sebagian siswa merasa kesulitan untuk mengembangkan ide menjadi sebuah cerita pendek. Siswa mengganggap menulis itu sebuah hal yang sukar. Melihat fenomena tersebut, maka guru harus inovatif dalam melaksanakan pembelajaran menulis. Mengajarkan menulis bukanlah hal yang mudah, apalagi jika siswa kurang berminat dalam pembelajaran 
menulis. Untuk itu, guru harus kreatif dan inovatif dalam menciptakan pembelajaran yang menyenangkan agar memudahkan siswa terampil menulis.

Salah satu cara mengoptimalkan proses pembelajaran menulis sehingga meningkatkan keterampialn menulis yaitu dengan memberikan media pembelajaran yang inovatif. Menurut Suryani dan Agung (2012: 137) menyatakan bahwa media pembelajaran merupakan semua yang dapat menyampaikan pesan, semua yan dapat merangsang pikiran, perasaan, dan kemauan siswa sehingga dapat mendorong siswa untuk belajar dengan baik. Hal tersebut menunjukkan media pembelajaran penting untuk diberikan kepada siswa SD karena media pembelajaran dapat merangsang pola pikir siswa.

Media pembelajaran dapat menumbuhkan motivasi belajar siswa, mengaktifkan siswa dalam proses pembelajaran, dan mengatasi keterbatasan indera, ruang, dan waktu. Selain itu, dengan adanya media pembelajaran materi pembelajaran akan lebih jelas maknanya sehingga siswa lebih mudah dalam memahami materi yan diberikan. Hal itu akan memudahan siswa dalam mencapai tujuan pembelajaran.

Uraian di atas menunjukkan bahwa dalam pembelajaran memerlukan sebuah media pembelajaran yang dapat membangkitkan minat siswa, semangat siswa, serta membangkitkan motivasi dan rangsangan kegiatan menulis siswa. Media pembelajaran yang dapat digunakan untuk membangkitkan minat siswa pada menulis adalah multimedia interaktif. Daryanto (2010: 52) menyatakan bahwa multimedia interaktif merupakan suatu multimedia yang dapat dioperasikan oleh pengguna, sehingga dapat memilih sesuai dengan apa yang dikehendaki untuk proses seterusnya. Dengan menggunakan multimedia interaktif, siswa dapat berlatih menulis cerita pendek tidak hanya di sekolah dan tidak hanya dengan panduan guru. Hal itu dikarenakan dalam multimedia interaktif mengkombinasikan teks, grafik, animasi, audio, dan video yang dapat digunakan siswa dalam belajar mandiri sehingga siswa dapat terus melatih keterampilan menulisnya kapan saja.

\section{METODE PENELITIAN}

Penelitian ini merupakan penelitian kualitatif deskriptif. Penelitian kualitatif yaitu penelitian yang menyajikan data yang berupa kata dan bahasa. Tujuan utama dari penelitian kualitatif deskriptif yaitu menggambarkan fakta secara sistematis mengunakan kata-kata, sedangkan tujuan dari penelitian ini yaitu untuk mendeskripsikan dan menggambarkan penerapan multimedia interaktif berbasis karakter pada pembelajaran menulis cerita pendek siswa kelas VI SDN Bulak 1.

Data pada penelitian ini yaitu data verbal dan juga data nonverbal. Data verbal pada penelitian ini yaitu hasil rekamanan penerapan multimedia interaktif berbasis karakter pada pembelajaran menulis cerita pendek siswa kelas VI SDN Bulak 1. Data nonverbal pada penelitian ini yaitu hasil evaluasi keterampilan menulis cerpen siswa kelas VI SDN Bulak 1 dengan menggunakan multimedia interaktif berbasis karakter.

Subjek penelitian ini yaitu satu orang guru kelas VI dan siswa kelas VI SDN Bulak 1 yang berjumlah siswa 15 siswa. Objek penelitian ini yaitu penerapan multimedia interaktif berbasis karakter pada pembelajaran menulis cerita pendek siswa kelas VI SDN Bulak 1.

Untuk mengumpulakan data pada penelitian ini digunakan teknik pengumpulan data yang terdiri dari (a) wawancara, (b) dokumentasi, dan (c) observasi, dan (d) tes. Data yang sudah terkumpul pada penelitian ini kemudian dianalisis. Analisis data yaitu suatu proses penyusunan data-data yang sudah terkumpul agar bisa ditafsirkan serta disimpulkan (Wiyono dan Burhannuddin, 2007: 90). Penelitian data yang digunakan pada penelitian ini analisis data kualitatif. Teknik analisis data akan dilakukan dengan 
teknik analisis data model interaktif, yaitu dengan menggunakan tiga cara yaitu (a) reduksi data, (b) penyajian data, dan (c) penarikan kesimpulan atau verifikasi.

\section{A. HASIL PENELITIAN DAN PEMBAHASAN}

Penelitian ini akan memaparkan hasil penerapan multimedia interaktif berbasis karakter pada pembelajaran menulis cerita pendek siswa kelas VI SDN Bulak 1. Berdasarkan dari wawancara dengan guru, dokumentasi perangkat pembelajaran dan hasil belajar siswa, observasi yang telah dilakukan di kelas 6 mata pelajaran Bahasa Indonesia, materi keterampilan menulis cerita pendek yaitu sebagai berikut.

1. Persiapan Pembelajaran

Hasil wawancara dengan guru kelas 6 SDN Bulak 1 menyatakan bahwa guru biasanya membuat silabus pada setiap semester, biasanya perangkat pembelajaran dibuat pada sebelum semester dimulai. Tidak hanya silabus, guru juga rencana pelaksanaan pembelajaran (RPP) ketika akan mengajar. Ketika membuat RPP, guru mencantumkan nilai-nilai karakter.

Pada tahap persiapan pembelajaran, hal-hal yang disiapkan yaitu perangkat pembelajaran dan media pembelajaran. Hal pertama yang dipilih yaitu menganalisis satndar kompetensi. Standar kompetensi yang digunakan pada pembelajaran kali ini yaitu Mengungkapkan pikiran, perasaan, dan informasi secara tertulis dalam bentuk formulir, ringkasan, dialog, dan parafrase. Setelah menentukan standar kompetensi, maka ditentukan juga kompetensi dasar yang akan digunakan. Kompetensi dasar yang digunakan yaitu Mengubah puisi ke dalam bentuk prosa dengan tetap memperhatikan makna puisi

Pada tahap persiapan RPP dibuat. Media yang digunakan untuk pembelajaran menulis cerita pendek yaitu menggunakan multimedia interaktif berbasis karakter. Pada RPP yang telah dibuat, terapat komponen standar kompetensi dan kompetensi dasar. Selain itu, dalam RPP juga terdapat komponen indikator dan tujuan pembelajaran. Komponen materi pembelajaran secara garis diletakkan pada pada lampiran. Langkah-langkah pembelajaran yang tersusun dalam RPP disesuaikan dengan model pembelajaran yan digunakan.

Pada saat menyiapkan RPP, LKS untuk guru juga disiapkan. Lembar kerja siswa berfungsi sebagai lembar kerja siswa pada saat menulis cerita pendek. Setelah RPP selesai, maka selanjutnya yaitu menyiapkan media pembelajaran. Media pembejaran yang digunakan yaitu multimedia interaktif berbasis karakter. Digunakannya multimedia interaktif karena dapat memudahkan siswa dalam belajar menulis cerita pendek. Media ini jua dianggap menarik karena pada SD tersebut belum pernah mengunakan multimedia interaktif sebagai media pembelajaran pada pelajaran Bahasa Indonesia.

2. Pelaksanaan Pembelajaran di kelas

Pembelajaran dengan mengunakan multimedia interaktif ini dilaksanakan pada siswa kelas 6 Sekolah dasar negeri Bulak 1. Materi yang digunakan dalam pembelajaran ini yaitu mengubah puisi ke dalam bentuk prosa. Pembelajaran dilaksanakan sesuai dengan rencana pembelajaran yang telah dibuat bersama. Di dalam pelaksanaan pembelajaran yang ada pada rencana pembelajaran, maka kegiatan pembelajaran ada tigga thapan yaitu yaitu kegiatan pembuka, kegiatan inti, dan kegiatan penutup.

a. Kegiatan Pembuka

Pembelajaran dilaksanakan setelah istirahat pertama. Kegiatan pembuka, dimulai dengan menyapa siswa dan mengucapkan salam yang dijawab oleh siswa kelas 6 secara serempak. Setelah menyapa dan mengucapkan salam pada siswa, lalu mengecek kehadiran siswa dengan memanggil nama siswa 
sesuai dengan data yang ada. Pada saat pelaksanaan pembelajaran dengan menggunakan multimedia interaktif ini, semua siswa kelas 6 hadir. Siswa yang berjumlah 15 itu duduk rapi pada tempatnya.. Setelah itu, mengecek kehadiran siswa, lalu ketua kelas memimpin doa. Selesai berdoa, siswa diberi yel yel yang bertujuan untuk menambah semangat siswa. Setelah siswa siap dan semangat, maka selanjutnya melakukan apersepsi kepada siswa. Apersepsi berupa pertanyaan-pertanyaan yang berisi seputar puisi dan cerita pendek. Pertanyaan-pernyataan yang diberikan kepada siswa yaitu sebagai berikut.

1) Siapa diantara kalian yang pernah membaca puisi?

2) Puisi bertema apa yang kalian baca?

3) Apa kalian tahu tentang makna puisi yang dibaca?

4) Pernah tidak kalian setelah membaca puisi lalu menulis cerita pendek dari puisi tersebut?

5) Apa cerita pendek itu?

6) Adakah yang pernah menulis cerita pendek?

Setelah memberikan apersepsi pada siswa, lankah selanjutnya yaitu menanggapi jawaban yang telah diberikan siswa kelas 6 tersebut. Setelah mengaitkan pertanyaan dengan jawaban siswa, lalu tujuan pembelajaran jua disampaikan pada siswa yaitu siswa dapat mengubah puisi menjadi sebuah prosa dengan tetap memperhatikan makna puisi.

b. Kegiatan Inti

Dalam kegiatan inti ini, pembelajaran dimulai dari menampilkan multimedia interaktif berbasis karakter pada siswa. Setelah itu, siswa diberi penjelasan tentang puisi, prosa, dan cerita pendek. Setelah menjelaskan perbedaan dari puisi dan prosa, llau siswa diberi pnejelasan tentang langkahlangkah mengubah puisi menjadi cerita pendek. Pada saat penjelasan dengan menggunakan multimedia interaktif, siswa sangat antusias karena siswa jarang mengunakan multimedia interaktif. Siswa fokus pada penjelasan yang telah diberikan. Setelah dijelaskan tentang langkah-langkah mengubah puisi, maka selanjutmya siswa diberi contoh bagaimana cara mengubah puisi menjadi sebuah prosa. Pada simulasi, siswa dituntun dari langkah 1 hingga tangkah terakhir dengan bimbingan. Pada simulasi ditampiilkan sebuah puisi yang akan diubah menjadi prosa. Siswa membaca puisi tersebut dengan seksama. Siswa tmpak tenang pada saat membaca puisi. Setelah selesai membaca puisi, siswa dituntun untuk menemukan tema, suasana, dan amanat pada puisi. Setelah itu, ditampilakn langkah 1 yang sudah terdapat pada multimedia interaktif. Setelah siswa paham denganlangkah 1, maka siswa akan diajak menuju langkah 2 yaitu menetukan tokoh dan penokohan. Pada tahap ini siswa sudah mulai berangan-angan akan memberi nama tokoh dengan watak yang bagaimana dalam cerita pendek yang akan dibuat. Setelah itu, siswa measuki langkah ketia yaitu menentukan alur. Pada tahap ini, siswa juga mulai menentukan alur yang akan digunakan, dalam contoh pada multimedia interaktif menggunakan alur maju. Dipilih alur maju karena alur maju yang paling sederhana sehingga cocok untuk siswa sekolah dasar. Setelah langkah ketiga, maka selanjutkan langkah keempat yaitu menentukan latar. Disini siswa juga harus menentukan latar tempat, waktu, dan suasananya. Pada contoh yang diberikan sudah ditentukan latar waktu siang hari, suasana sedih dan gembira, tmpatnya bandara dan amsterdam. Langkah kelima yaitu memberi judul cerita dan memulai untuk menulis cerita. Setelah selesai memberikan contoh, maka siswa diberi kesempatan untuk bertanya. Ada beberapa siswa yang bertanya tentang cara 
menentukan suasana, maka selanjutnya diberi penjelasan cara menentukan suasana.

Setelah selesai menjelaskan, siswa diberi 10 pertanyaan tentang apa yang sudah dijelaskan. Pertanyaan ini terdapat pada multimedia interaktif. Setelah selesai, siswa diberi kesempatan lagi untuk bertanya. Setelah tidak ada pertanyaan dari siswa maka kelas dibentuk menjadi 3 kelompok. Tiap kelompok ada 5 siswa. Setiap kelompok diberi lembar kerja siswa. Pada lembar kerja siswa terdapat dua soal uraian. Yang pertama soal untuk menentukan tema, suasana, dan amanat pada puisi. Yang kedua soal berupa perintah untuk mengubah puisi menjadi sebuah prosa. Siswa diberi kesempatan bertanya tentang tugas yang sudah diberikan. Tidak ada siswa yang bertanya, hal yang menunjukkan bahwa siswa sudah paham dengan soal-soal yang ada pada lembar kerja siswa. Setelah itu, siswa ditunjukkan puisi yang akan dianalisis dan diubah menjadi sebuah prosa pada multimedia interaktif.

Siswa tampak membaca puisi yang terdapat pada multimedia interaktif dengan tenang dan konsentrasi. Setelah selesai membaca, siswa berdiskusi dengan kelompoknya. Setiap kelompok mulai menemukan tema, suasana, dan amanat pada puisi. Berdasarkan ketia hal tersebut maka siswa akan menentukan tokoh dan penokohan. Setelah itu mennetukan alur, menetukan latar, judul dan menuliskannya dalam sebuah cerita pendek sederhana. Pada saat menulis cerita pendek setiap kelompok bekerja bersama untuk menyelesaikan cerita yang mereka buat. Mereka tampak semangat dalam menyelesaikan cerita yang dibuat.

c. Kegiatan Penutup

Kegiatan terakhir dalam pembelajaran yaitu kegiatan penutup. Pada kegitatan penutup ini, siswa diberi ulasan tentang pembelajaran yang telah baru saja dilaksanakan. Siswa diberi penguatan tentang pembelajaran. Selain itu, siswa juga diberi kesempatan untuk bertanya hal-hal yang belum dipahami. Selesai diberi penguatan, maka siswa menyimpulkan pembelajaran. Siswa juga diberi nasehat bahwa menulis itu mudah jika sering dilatih. Siswa tidak boleh takut jika ada tugas untuk menulis. Siswa harus berusaha agar menjadi mudah dalam menulis. Setelah itu, pembelajaran ditutup.

3. Hasil Evaluasi menulis cerita pendek Siswa Kelas VI SDN Bulak 1 dengan multimedia interaktif

Berdasarkan dari hasil evaluasi yang telah diberikan, pembelajaran mengubah puisi menjadi prosa sudah cukup baik. Sebagian besar siswa kelas 6 SDN Bulak 1 sudah mencapai KKM yang sudah ditetapkan yaitu 75. Pada pembelajaran menulis cerpen ini nilai rata-rata kelas 6 SDN Bulak 1 yaitu sebesar $78,3 \%$ dari total siswa 15 orang. Pada SDN Bulak 1, nilai terendah yaitu 70 dan nilai tertinggi 85 . Ada 5 siswa yang memperoleh nilai 70 . Siswa yang memproleh nilai 80 sebanyak 5 siswa, sedangkan siswa memperoleh nilai 85 sebanyak 5 siswa. Berdasarkan hal tersebut, maka terbukti bahwa sebagian besar siswa atau sekitar $66,7 \%$ siswa sudah mendapatkan nilai tuntas. Dan masih ada 5 siswa atau sebesar $33,3 \%$ siswa masih belum mendapatkan nilai tuntas.

\section{SIMPULAN}

Melihat dari paparan yang sudah diuaraikan di atas, maka disimpulkan bahwa penerapan multimedia interaktif berbasis karakter pada pembelajaran menulis cerita pendek siswa kelas VI SDN Bulak 1 ini sudah berjalan sesuai dengan yan sudah terencakan dalam rencana pelaksanaan pembelajaran. Pada pelaksanaan pembelajaran sudah mengacu pada rencana pembelajaran, dalam 
pelaksaan pembelajaran sudah terdapat kegiatan pembuka, kegiatan inti, dan kegiatan penutup. Pada pembelajaran ini sudah diberikan tes meubah puisi menjadi sebuah prosa. Berdasarkan hasil evaluasi yang telah diberikan, pembelajaran menulis cerita pendek sudah baik. Dari hasil evaluasi diketahui nilai rata-rata kelas 6 SDN Bulak 1 yaitu sebesar 78,3\% dari total siswa 15 orang. Sebagian besar siswa atau sekitar $66,7 \%$ siswa sudah mendapatkan nilai tuntas, sedangkan siswa yang belum mendapatkan nilai tuntas sebesar $33,3 \%$.

Diharapkan, semua guru sekolah dasar akan memotivasi dirinya untuk selalu berpikir kreatif dan berinovatif untuk menciptakan media-media pembelajaran yang menarik sehingga meningkatkan kemampuan siswa. Hal itu dikarenakan media pembelajaran dapat membantu siswa dalam menerima pembelajaran dan juga dapat menarik minat belajar siswa.

\section{DAFTAR PUSTAKA}

Anwas, Oos M. 2011. Membangun Media Masa Publik dalam Menanamkan Pendidikan Karakter. Ina. J. Dikbud, 17(6): 681-691.

Budiarti, M. 2016. Implementasi Pendidikan Karakter Melalui Pembiasaan Berbaris Sebelum Pulang Terhadap Karakter Disiplin Siswa Sekolah Dasar. Pendidikan Guru Sekolah Dasar S1, 1(01).

Darmadi, Kaswan. 1996. Meningkatkan Kemempuan Menulis. Yogyakarta: Andi Offset.

Daryanto. 2010. Media Pembelajaran.Yogyakarta:Gava Media

Raharjo, Sabar Budi. 2010. Pendidikan Karakter Sebagai Upaya Menciptakan Akhlak Mulia. Ina. J. Dikbud, 16(3): 229-238).

Saddhono, Kundharu dan Slamet. 2012. Meningkatkan Keterampilan Berbahasa Indonesia. Bandung: Karya Putra Darwati.

Sholikhah, O. H. 2016. Problematika Penerapan Model Pembelajaran Kooperatif Tipe Group Investigation (GI) dan Alternatif Pemecahanannya. Premiere Educandum: Jurnal Pendidikan Dasar dan Pembelajaran, 5(02).

Suryani, N dan Agung, L. 2012. Strategi Belajar-Mengajar. Yogyakarta: Ombak.

Tarigan, Henry Guntur. 2008. Menulis Sebagai Suatu Keterampilan Berbahasa. Bandung: Angkasa.

Widyaningrum, H. K. 2016. Penggunaan Media Audio untuk Meningkatkan Kemampuan Menyimak Dongeng Anak PADA Siswa Kelas IV Sekolah Dasar. Premiere Educandum: Jurnal Pendidikan Dasar dan Pembelajaran, 5(02).

Wiyono, Bambang Budi dan Burhanuddin. (2007). Metodologi Penelitian (Pendekatan Kuantitif, Kualitatif, dan Action Research). Malang: FIP Universitas Negeri Malang. 